\title{
$14: 89155209-88697458$
}

National Cancer Institute

\section{Source}

National Cancer Institute. 14:89155209-88697458. NCI Thesaurus. Code C41958.

Physical location of CHES1_Gene 